\title{
PEMODELAN KASUS COVID-19 MENGGUNAKAN MODEL REGRESI NONPARAMETRIK
}

\author{
Studi Kasus di Jakarta
}

\section{(MODELING THE CASE OF COVID-19 USING A NONPARAMETRIC REGRESSION MODEL A CASE STUDY IN JAKARTA)}

\author{
Rita Diana ${ }^{1}$, Rory ${ }^{1}$ \\ Badan Pusat Statistik Provinsi Sumatera Barat ${ }^{1}$ \\ E-mail: rita.diana@bps.go.id
}

\begin{abstract}
ABSTRAK
Pemodelan kasus positif COVID-19 perhari sangat sulit bahkan banyak gejala menunjukkan bahwa data yang diperoleh tidak menunjukkan suatu pola hubungan yang mudah untuk digambarkan. Untuk mengatasi kesulitan-kesulitan tersebut digunakan model regresi nonparametrik. Tujuan penelitian ini adalah medapatkan model terbaik dari pemodelan data kasus baru perhari COVID-19 di Jakarta menggunakan model regresi nonparametrik berupa regresi spline (cubic spline), smoothing spline dan MARS. Data kasus baru perhari COVID-19 di Jakarta yang digunakan adalah data kasus baru mulai tanggal 16 Maret 2020 sampai dengan 15 Agustus 2020. Data tersebut dibagi dalam dua kelompok yaitu data tanggal 16 Maret 2020 sampai dengan 6 Agustus 2020 sebagai data in sample yang digunakan sebagai pembentuk model regresi nonparametrik, dan data tanggal 7 Agustus 2020 sampai dengan 15 Agustus 2020 sebagai data out sample yang digunakan untuk memvalidasi model regresi nonparametrik. Hasil penelitian menunjukkan model regresi nonparametrik berupa MARS dengan $\mathrm{BF}=46, \mathrm{MI}=1$ dan $\mathrm{MO}=1$ merupakan model terbaik dan sangat akurat dalam melakukan prediksi untuk kasus COVID-19 di Jakarta.
\end{abstract}

Kata kunci: COVID-19, MARS, Spline, Nonparametrik

\begin{abstract}
Modeling positive cases of COVID-19 per day is very difficult, even though many symptoms show that the data obtained does not show a pattern of relationships that is easy to describe. To overcome these difficulties, a nonparametric regression model is used. The purpose of this study is to obtain the best model from modeling new cases of COVID-19 per day in Jakarta using nonparametric regression models in the form of spline regression (cubic spline), smoothing spline and MARS. The data on new cases per day for COVID-19 in Jakarta used is data on new cases from March 162020 to August 15 2020. The data is divided into two groups, namely data from March 162020 to August 6, 2020 as in sample data used for nonparametric regression model formers, and data from 7 August 2020 to 15 August 2020 as out-sample data used to validate nonparametric regression models. The results showed that the nonparametric regression model in the form of MARS with $B F=46, M I=1$ and $M O=1$ is the best and very accurate model in making predictions for the COVID-19 case in Jakarta.
\end{abstract}

Keywords: COVID-19, MARS, Spline, Nonparametric

\section{PENDAHULUAN}

Coronavirus disease 2019 atau yang lebih dikenal COVID-19 adalah penyakit menular yang disebabkan oleh jenis virus baru bernama sindrom pernafasan akut coronavirus 2 (SARS-CoV-2), yang diketahui berasal dari kota Wuhan, Cina pada Desember 2019 (Susilo, dkk., 2019). Penyebaran virus ini telah sampai ke beberapa negara termasuk Indonesia. Di Indonesia virus ini pertama kali muncul di Jakarta. Jakarta sebagai ibu kota negara Indonesia dengan tingkat kepadatan penduduk yang tinggi memiliki pertumbuhan infrastruktur dan ekonomi yang juga 
cukup tinggi. Fenomena ini membuat Jakarta menjadi kota dengan penduduk terbanyak yang terpapar COVID-19. Sepertiga kasus COVID-19 nasional terjadi di Jakarta. Pemerintah selama ini selalu memberikan perhatian yang besar terhadap upaya penghentian penyebaran virus ini. Para ahli juga telah banyak yang melakukan penelitian terkait penyebaran COVID-19, diantaranya Teguh, dkk. (2020) menggunakan model SEIR (Susceptible-Exposed-Infected-Recovered) untuk melakukan perhitungan jumlah munculnya kasus baru akibat seseorang yang terinfeksi COVID-19 masuk ke dalam suatu populasi yang sepenuhnya sehat dan potensial untuk terinfeksi COVID-19. Selanjutnya, Aldila, dkk. (2020) membuat model matematika terkait penyebaran COVID-19 dengan pengembangan model SEIR. Ekum dan Ogunsanya (2020) melakukan pemodelan kasus COVID-19 menggunakan Hierarchical Polynomial Regression Models. Demertzis, et al. (2020) memodelkan kasus COVID-19 di Yunani menggunakan model regresi spline.

Pemodelan kasus positif COVID-19 perhari sangat sulit bahkan banyak gejala menunjukkan bahwa data yang diperoleh tidak menunjukkan suatu pola hubungan yang mudah untuk digambarkan. Untuk mengatasi kesulitan-kesulitan di atas, maka digunakan model regresi nonparametrik. Dalam model regresi nonparametrik, fungsi yang tidak diketahui polanya dapat diestimasi dengan menggunakan fungsi spline meskipun fungsi lain, seperti polinomial lokal atau kernel, juga tersedia (Loader, 2004). Fungsi spline memiliki fleksibilitas yang tinggi dan mampu menangani pola hubungan data yang perilakunya berubah-ubah pada sub-sub interval tertentu (Eubank, 1999). Hal ini juga telah ditunjukkan oleh Liang (2006) dan Aydin (2008). Pendekatan regresi nonparametrik secara adaptive juga telah banyak diminati. Salah satu contohnya adalah Multivariate Adaptive Regression Spline (MARS) (Breiman, 1993). Model MARS juga menghasilkan prediksi variabel respon yang akurat, serta menghasilkan model yang kontinu pada knot dan dapat mengidentifikasi adanya fungsi linier dan aditif (Friedman, 1991).

Sampai saat ini, estimasi fungsi spline dalam model regresi nonparametrik diikuti tiga bentuk yakni regresi spline (truncated spline, cubic spline, B-spline, MARS), penalized spline (P-spline) dan smoothing spline. Estimator regresi spline sangat tergantung pada banyak knot dan dimana lokasi knot-knot tersebut, sedangkan smoothing spline sangat tergantung pada parameter smoothing. Pemilihan knot dan parameter smoothing dapat dilakukan dengan metode Generalized Cross Validation (GCV), GCV.

Tujuan penelitian ini adalah medapatkan model terbaik dari pemodelan data kasus baru perhari COVID-19 di Jakarta menggunakan model regresi nonparametrik berupa regresi spline (cubic spline), smoothing spline dan MARS.

\section{METODE}

Model regresi nonparametrik digunakan jika pola hubungan antara variabel respon dengan variabel prediktor tidak dapat digambarkan dengan suatu fungsi tertentu. Misalkan diberikan data berpasangan $\left(z_{j}, y_{j}\right), j=1, \ldots, n$ dengan $y_{j}$ adalah variabel respon pengamatan ke-j dan $z_{j}$ merupakan variabel prediktor pengamatan ke-j yang bentuk pola hubungannya dengan variabel respon tidak menunjukkan pola tertentu. Hubungan antara variabel respon $y_{j}$ dengan variabel predictor $z_{j}$ diasumsikan mengikuti model regresi nonparametrik berikut:

$$
y_{j}=f\left(z_{j}\right)+\varepsilon_{j}, j=1, \ldots, n \text {. }
$$

Error random $\varepsilon_{\mathrm{j}}$ diasumsikan saling bebas dengan mean nol dan varians $\sigma^{2}$. Bentuk kurva regresi f tidak diketahui dan diasumsikan termuat di dalam ruang fungsi yang memiliki sifat kontinu dan diferensiabel, salah satunya adalah ruang Sobolev (Wahba, 1990). Permasalahan dalam analisis regresi nonparametrik adalah mencari estimasi kurva regresi $f$ dengan menggunakan data sampel.

Regresi spline adalah model regresi nonparametrik (1) dimana f merupakan fungsi spline yang menggunakan fungsi basis diantaranya truncated power, cubic spline dan B-spline. Fungsi basis merupakan masing-masing pola perilaku regresi antar knot. Knot adalah batas dari suatu fungsi basis. Knot merupakan akhir dari satu fungsi basis sebelumnya dan merupakan awal dari fungsi basis berikutnya. Bentuk fungsi basis spline sebagai berikut: 


$$
f\left(z_{j}\right)=\sum_{v=0}^{m} a_{v-1} z_{j}^{v}+\sum_{q=1}^{k} a_{m+q}\left(z_{j}-K_{q}\right)_{+}^{m} \text { dengan }\left(z_{j}-K\right)_{+}^{m}= \begin{cases}\left(z_{j}-K\right)^{m}, & z_{j} \geq K \\ 0, & z_{j}<K\end{cases}
$$

dimana:

$\mathrm{K}_{\mathrm{q}} \quad=$ titik knot

$\mathrm{m}=$ derajat (orde) spline truncated dimana untuk $\mathrm{m}=2$ merupakan fungsi spline linear, $\mathrm{m}=3$ merupakan fungsi spline kuadratik dan $\mathrm{m}=4$ merupakan fungsi spline kubik

Untuk mendapatkan estimator regresi spline dalam regresi nonparametrik dapat menggunakan pendekatan OLS (Eubank, 1999), yaitu $\hat{\mathbf{f}}=\mathbf{B Y}$ dengan $\mathbf{Y}=\left((\mathbf{Z}(K))^{\prime} \mathbf{Z}(K)\right)^{-1}(\mathbf{Z}(K))^{\prime} \mathbf{y}$ dan $\mathbf{B}$ adalah matrik yang berisi fungsi basis berupa:

$$
B=\left[\begin{array}{cccccccc}
1 & z_{1} & z_{1}^{2} & L & z_{1}^{m} & \left(z_{1}-K_{1}\right)_{+}^{m} & L & \left(z_{1}-K_{k}\right)_{+}^{m} \\
1 & z_{2} & z_{2}^{2} & L & z_{2}^{m} & \left(z_{2}-K_{1}\right)_{+}^{m} & L & \left(z_{2}-K_{k}\right)_{+}^{m} \\
M & M & M & O & M & M & O & M \\
1 & z_{n} & z_{n}^{2} & L & z_{n}^{m} & \left(z_{n}-K_{1}\right)_{+}^{m} & L & \left(z_{n}-K_{k}\right)_{+}^{m}
\end{array}\right]_{n \times(m+k+1)}
$$

Estimator smoothing spline dalam regresi nonparametrik diperoleh dengan menyelesaikan optimasi Penalized Least Square (Kimeldorf dan Wahba (1971) yaitu $\hat{\mathbf{f}}_{\lambda}=\mathbf{Z} \hat{\mathbf{a}}+\mathbf{V} \hat{\boldsymbol{\beta}}$ dengan

$$
\begin{aligned}
& \hat{\mathbf{a}}=\left(\mathbf{Z}^{\prime} \mathbf{U}^{-1} \mathbf{Z}\right)^{-1} \mathbf{Z}^{\prime} \mathbf{U}^{-1} \mathbf{Y}, \hat{\boldsymbol{\beta}}=\mathbf{U}^{-1}\left(\mathbf{I}-\mathbf{Z}\left(\mathbf{Z}^{\prime} \mathbf{U}^{-1} \mathbf{Z}\right)^{-1} \mathbf{Z}^{\prime} \mathbf{U}^{-1}\right) \mathbf{y}, \mathbf{U}=\mathbf{V}+n \lambda \mathbf{I}, \mathbf{Z}=\left\{\phi_{v}\left(z_{j}\right)\right\}_{j=1, v=1}^{n, m}, \\
& \phi_{v}\left(z_{j}\right)=z_{j}^{v-1} /(v-1) !, \quad \mathbf{V}=\left\{\psi\left(z_{j}, z_{l}\right)\right\}_{j=1, l=1}^{n, n}, \operatorname{dan} \psi\left(z_{j}, z_{l}\right)=\int_{a}^{b} \frac{\left(z_{j}-u^{*}\right)_{+}^{m-1}\left(z_{l}-u^{*}\right)_{+}^{m-1}}{[(m-1) !]^{2}} d u^{*} .
\end{aligned}
$$

MARS pertama kali dikembangkan oleh Friedman (1991), yang merupakan pendekatan regresi nonparametrik untuk memprediksi suatu nilai dari variabel respon dari sekumpulan/set variabel prediktor tanpa asumsi mengenai hubungan fungsi dasar antara variabel respon dengan variabel prediktor. Model MARS juga menghasilkan prediksi variabel respon yang akurat, serta menghasilkan model yang kontinu pada knot dan dapat mengidentifikasi adanya fungsi linier dan aditif (Friedman, 1991). Kemampuan MARS untuk pemodelan data time series telah dilakukan oleh Lewis dan Stevens (1990), di mana data deret waktu diperlakukan sebagai variabel prediktor. Dalam beberapa tahun terakhir, penerapan MARS telah banyak dilakukan untuk memodelkan berbagai data seperti prediksi saluran radio seluler (Hass dan Kubin, 1998) dan deteksi intrusi dalam keamanan sistem informasi (Mukkamala dan Sung, 2003). Hasil penelitian Kisi dan Parmar (2016) menjelaskan keuntungan menggunakan model MARS dalam memprediksi polusi air sungai yakni dapat menjelaskan hubungan nonlinier yang kompleks dari variabel input dan variabel output. MARS juga telah diterapkan untuk memprediksi rata-rata bulanan nilai tukar mata uang asing (Abraham, 2002), untuk model penilaian kredit (Lee dan Chen, 2005), dan untuk data mining tentang pola kanker payudara (Chou, dkk., 2004). Dalam litertur di atas, hasil penelitannya menyatakan bahwa MARS baik digunakan untuk peramalan atau untuk data mining dalan menemukan model estimasi dengan pendekatan paling baik terhadap suatu fungsi sesungguhnya.

MARS merupakan usefull model yang dapat diperoleh meskipun dalam kondisi dimana hubungan antara variabel prediktor dan variabel respon non-monotone dan sukar untuk didekati dengan model parametrik (Hardle, 1994). Metode ini merupakan pengembangan dari pendekatan RPR yang masih memiliki kelemahan dimana model yang dihasilkan tidak kontinu pada knot. MARS merupakan kombinasi yang kompleks dari spline dan rekursif partisi. Model MARS digunakan untuk mengatasi kelemahan RPR yaitu menghasilkan model yang kontinu pada knot. Perbaikan yang dilakukan untuk mengatasi keterbatasan RPR, antara lain menghasilkan fungsi basis menjadi :

$$
B_{m}^{(q)}(\mathbf{x})=\prod_{k=1}^{K_{m}}\left[s_{k m} \cdot\left(z_{(k, m)}-t_{k m}\right)\right]_{+}^{q}
$$

Estimator model MARS didapatkan melalui PLS, yaitu 


$$
\hat{f}(z)=a_{0}+\sum_{m=1}^{M} a_{m} \prod_{k=1}^{K_{m}}\left[s_{k m} \cdot\left(z_{(k, m)}-t_{k m}\right)\right]_{+}^{q}
$$

dimana

$\mathrm{M} \quad$ = banyaknya fungsi basis (nonconstant basis function)

$K_{m} \quad=$ derajat interaksi

$\mathrm{Z}(\mathrm{k}, \mathrm{m})=$ variabel prediktor

$\mathrm{t}_{\mathrm{km}} \quad=$ nilai $k$ not dari variabel prediktor $\mathrm{z}_{\mathrm{v}}(\mathrm{k}, \mathrm{m})$

Salah satu hal penting dalam estimator regresi spline adalah mencari estimator regresi spline yang paling sesuai untuk sekumpulan data. Estimator regresi spline sangat tergantung pada knot, sehingga pemilihan banyak knot dan lokasi titik knot merupakan hal yang penting dalam mencari estimator regresi spline yang paling sesuai. Sedangkan pada estimator smoothing spline sangat tergantung pada parameter smoothing, sehingga pemilihan parameter smoothing merupakan hal yang penting dalam mencari estimator smoothing spline yang paling sesuai. Wahba (1990) dan Wang (1998) memperlihatkan bahwa jika nilai knot dan parameter smoothing sangat kecil maka akan memberikan estimator spline yang sangat kasar. Sebaliknya, jika nilai knot dan parameter smoothing sangat besar maka akan menghasilkan estimator spline yang sangat mulus. Akibatnya perlu dipilih knot dan parameter smoothing yang optimal agar diperoleh estimator spline yang paling sesuai untuk data.

Dalam pemilihan titik knot dan parameter smoothing pada model nonparametrikdapat menggunakan Generalized Cross Validation (GCV). Kriteria GCV untuk regresi spline didefinisikan sebagai berikut (Eubank, 1999):

$$
\operatorname{GCV}(K)=\frac{n^{-1}\left(y_{i}-y_{i}\right)^{2}}{\left[n^{-1} \operatorname{trace}(\mathbf{I}-\mathbf{A}(K)]^{2}\right.}
$$

dengan $\mathbf{A}(K)=\mathbf{Z}(K)\left(\mathbf{Z}(K)^{\prime} \mathbf{Z}(K)\right)^{-1} \mathbf{Z}(K)$. Banyaknya titik knot dan lokasi titik-titik knot optimum ditentukan ketika $\mathrm{GCV}(K)$ mencapai nilai minimum. Kriteria GCV untuk smoothing spline didefinisikan sebagai berikut (Wahba, 1983):

$$
\operatorname{GCV}(\lambda)=\frac{n^{-1}\left(y_{i}-y_{i}\right)^{2}}{\left[n^{-1} \operatorname{trace}(\mathbf{I}-\mathbf{A}(\lambda))\right]^{2}},
$$

dengan $\mathbf{A}(\lambda)=\mathbf{I}-n \lambda \mathbf{U}^{-1}\left(\mathbf{I}-\mathbf{Z}\left(\mathbf{Z}^{\prime} \mathbf{U}^{-1} \mathbf{Z}\right)^{-1} \mathbf{Z}^{\prime} \mathbf{U}^{-1}\right)$. Nilai parameter smoothing $(\lambda)$ optimal diperoleh dengan meminimumkan $\operatorname{GML}(\lambda)$.

Pada model MARS, pemilihan model menggunakan metode stepwise yaitu memilih fungsi basis yang dihasilkan dari forward stepwise dengan meminimumkan nilai GCV. Nilai GCV didefinisikan sebagai berikut (Friedman (1991):

$$
\mathrm{GCV}(\mathrm{m})=\frac{\frac{1}{n} \sum_{i=1}^{n}\left[y_{i}-\hat{f}_{m}\left(x_{i}\right)\right]^{2}}{\left[1-\frac{\tilde{C}(m)}{n}\right]^{2}}
$$

dengan $C(M)=$ Trace $\left[B\left(B^{\top} B\right)^{-1} B^{\top}\right]+1$ adalah banyaknya parameter yang diestimasi dan $\tilde{C}(M)$ $=C(M)+d . M$, nilai $d$ yang terbaik berada dalam interval $2 \leq \mathrm{d} \leq 4$.

Data yang akan digunakan adalah data sekunder yang bersumber dari web resmi Jakarta Tanggap COVID-19 di https://corona.jakarta.go.id/id/data-pemantauan. Data kasus baru perhari COVID-19 di Jakarta yang digunakan adalah data kasus baru mulai tanggal 16 Maret 2020 sampai dengan 15 Agustus 2020. Data tersebut dibagi dalam dua kelompok yaitu data tanggal 16 Maret 2020 sampai dengan 6 Agustus 2020 sebagai data in sample yang digunakan sebagai pembentuk model regresi nonparametrik, dan data tanggal 7 Agustus 2020 sampai dengan 15 Agustus 2020 sebagai data out sample yang digunakan untuk memvalidasi model regresi nonparametrik. 
Metode analisis yang digunakan dalam penelitian ini yaitu analisis pemodelan data kasus baru perhari COVID-19 di Jakarta menggunakan model regresi nonparametrik berupa regresi spline (cubic spline), smoothing spline dan MARS. Hasil prediksi dari ketiga model dibandingkan melalui Mean Square Error (MSE), R-Square ( $\mathrm{R}^{2}$ ) dan Mean Absolute Percentage Error (MAPE).

\section{HASIL DAN PEMBAHASAN}

Sebelum melakukan pemodelan COVID-19 dengan regresi nonparamterik, terlebih dahulu dilakukan scatter plot kasus COVID-9 per hari untuk melihat pola hubungannya dan melakukan uji nonlinearitas Ramsey Regression Equation Specification Error Test (Ramsey RESET) (Kim, dkk., 2004). Berdasarkan hasil uji Ramsey RESET data kasus COVID-19 per hari diperoleh nilai statistik RESET adalah 105,79 dan nilai $p$-value adalah < 2,2e-16. Karena nilai $p$-value kurang dari 0,05 maka dapat disimpulkan bahwa data kasus COVID-19 per hari di Jakarta sebaiknya menggunakan model non-linear lainnya. Keterbatasan informasi, bentuk fungsi dan tidak jelasnya pola hubungan antara variabel respon dengan prediktor merupakan pertimbangan digunakannya pendekatan regresi nonparametrik (Eubank, 1988). Sehingga berdasarkan scatter plot dan hasil uji Ramsey RESET kasus COVID-19 di Jakarta dapat menggunakan model regresi nonparametrik. Pada penelitian ini, akan diterapkan metode regresi nonparametrik berupa cubic spline, smoothing spline dan MARS.

Untuk mendapatkan model terbaik dengan menggunakan cubic spline dilakukan dengan memilih titik knot dan jumlah knot optimal. Pemilihan model cubic spline terbaik dilakukan dengan membandingkan nilai $\mathrm{GCV}(K)$. Model yang menghasilkan nilai $\mathrm{GCV}(K)$ paling minimum akan ditetapkan sebagai model terbaik. Dalam pengolahan ini, jumlah titik knot optimal yang digunakan sebanyak 3 yakni 28, 48 dan 100 dengan nilai $\mathrm{GCV}(K)$ minimum adalah 2.806,65. Sedangkan untuk mendapatkan model terbaik dengan menggunakan smoothing spline dilakukan dengan memilih parameter smoothing optimal. Pemilihan model smoothing spline terbaik dilakukan dengan membandingkan nilai $\operatorname{GML}(\lambda)$. Model yang menghasilkan nilai $\operatorname{GML}(\lambda)$ paling minimum akan ditetapkan sebagai model terbaik. Dalam pengolahan ini, nilai parameter smoothing optimal yang digunakan yakni 0,8428437 dengan nilai $\operatorname{GML}(\lambda)$ minimum adalah 2.955,06.

Untuk mendapatkan model terbaik dengan menggunakan MARS dilakukan dengan mengkombinasikan komposisi jumlah maksimum basis function (BF), maximum interaction (MI) dan minimum number of observation (MO). Pemilihan model MARS yang terbaik dilakukan dengan membandingkan nilai $\mathrm{GCV}(m)$. Model yang menghasilkan nilai $\mathrm{GCV}(m)$ paling minimum akan ditetapkan sebagai model terbaik dan akan digunakan untuk analisis berikutnya. Berdasarkan hasil pengolahan data, maka dipilih model yang dianggap layak berdasarkan nilai $\operatorname{GCV}(m)$ minimum yaitu model dengan jumlah basis fungsi $=46$, minimum number of observation $=1$, maksimum interaksi $=1$. Model ini menghasilkan nilai GCV $(m)$ sebesar $1.779,99$.

Untuk melihat kinerja prediksi model yang dihasilkan secara visual, dibuat plot perbandingan pola hasil prediksi kasus COVID-19 untuk data in sample dari masing-masing model yang disajikan dalam Gambar 1.

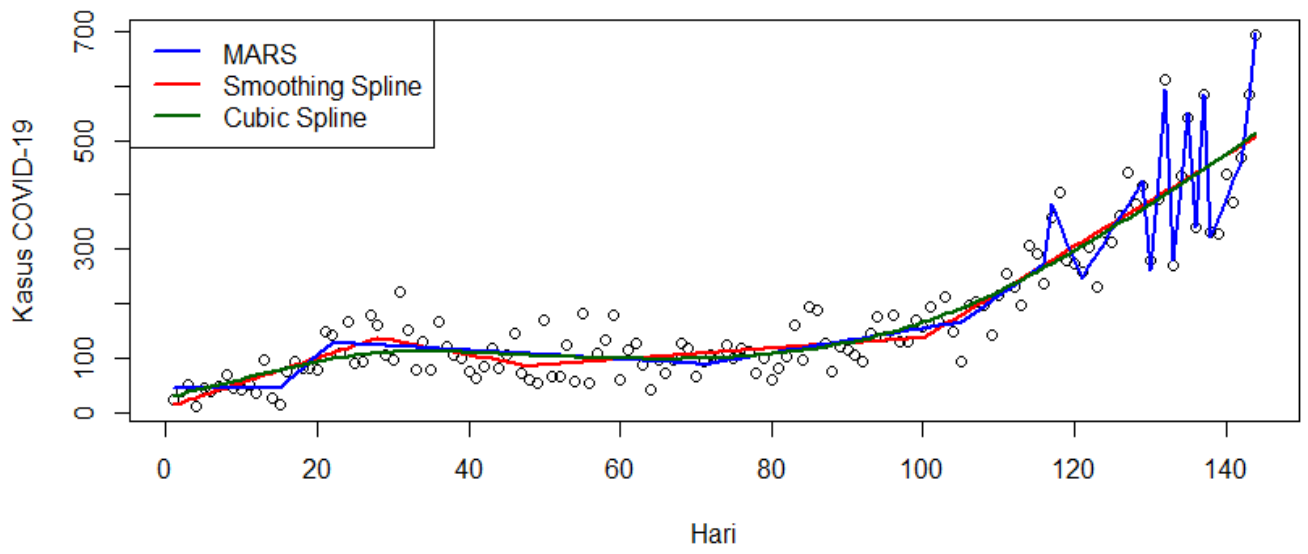


Gambar 17. Plot data COVID-19 di Jakarta dengan hasil prediksi COVID-19 pada data In Sample Menggunakan Model Regresi Nonparametrik Berupa Cubic Spline, Smoothing Spline dan MARS

Untuk melihat kinerja prediksi masing-masing model regresi nonparametrik digunakan nilai Mean Square Error (MSE) dan R-square $\left(\mathrm{R}^{2}\right)$. Nilai MSE dan $\mathrm{R}^{2}$ dari masing-masing model regresi nonparamterik berupa Cubic spline, Smoothing Spline dan MARS untuk data in sample dapat dilihat pada Tabel 1.

Tabel 18. Nilai MSE dan $\mathrm{R}^{2}$ model regresi nonparametrik berupa Cubic spline, Smoothing Spline dan MARS pada data In Sample

\begin{tabular}{ccc}
\hline Model Regresi Nonparamtrik & MSE & $\mathrm{R}^{2}$ \\
\hline Cubic Spline & $2.806,62$ & 0,839 \\
Smoothing Spline & $2.709,90$ & 0,897 \\
MARS & $1.213,66$ & 0,938 \\
\hline
\end{tabular}

Hasil penelitian menunjukkan model regresi nonparametrik berupa MARS merupakan model terbaik untuk pemodelan kasus COVID-19 di Jakarta karena memiliki nilai MSE paling kecil dan $\mathrm{R}^{2}$ paling besar dibandingkan model regresi nonparametrik berupa cubic spline dan smoothing spline. Untuk melihat apakah model regresi nonparametrik berupa MARS dengan $\mathrm{BF}=46, \mathrm{MI}=1$ dan $\mathrm{MO}=1$ layak digunakan untuk prediksi, maka model tersebut perlu dicobakan terhadap data out sampe/ dan dihitung MAPE-nya. Hasil prediksi kasus COVID-19 untuk data out sample dari model tersebut disajikan dalam Gambar 2.

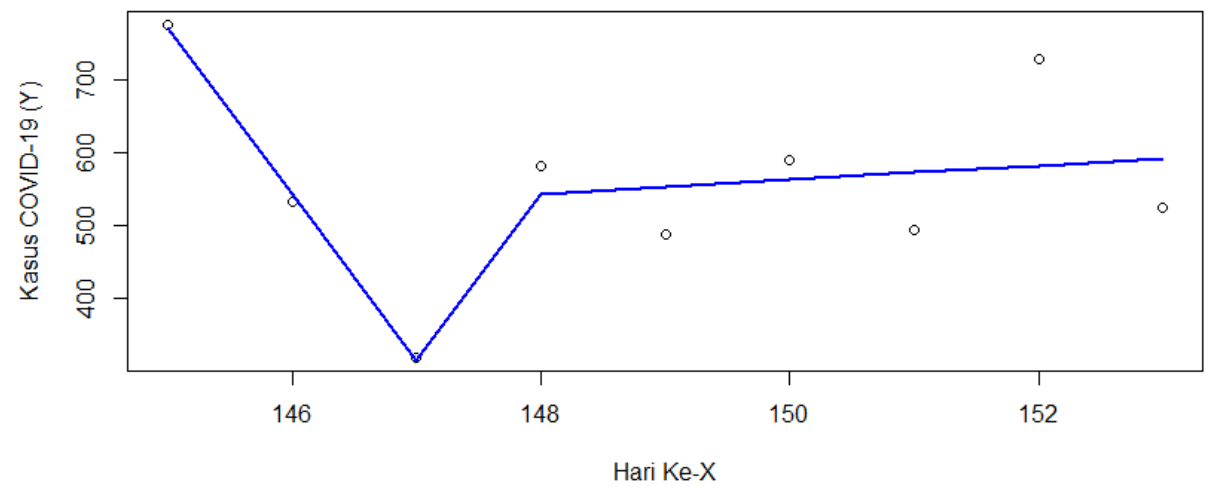

Gambar 2. Plot data COVID-19 di Jakarta dengan hasil prediksi COVID-19 pada data Out Sample Menggunakan Model Regresi Nonparametrik berupa MARS dengan $\mathrm{BF}=46, \mathrm{MI}=1$ dan $\mathrm{MO}=1$

Hasil prediksi data out sampe/ diperoleh nilai MAPE sebesar 8,59 persen. Berdasarkan kriteria interpretasi penilaian MAPE (Lewis, 1982), model regresi nonparametrik berupa MARS dengan $\mathrm{BF}=46, \mathrm{MI}=1$ dan $\mathrm{MO}=1$ sudah dapat dikatakan sangat akurat dalam melakukan prediksi

\section{KESIMPULAN}

Berdasarkan hasil penelitian, prediksi kasus COVID-19 di Jakarta menggunakan model regresi nonparamterik berupa MARS lebih baik dibandingkan dengan hasil prediksi menggunakan cubic spline dan smoothing spline. Hal ini terlihat dari nilai MSE dan $\mathrm{R}^{2}$ yang dihasilkan ketiga metode tersebut berdasarkan data in sample dan nilai MAPE berdasarkan data out sample. Untuk analisis 
lebih lanjut bisa dilakukan prediksi kasus COVID-19 dengan menggunakan model regresi nonparametrik berupa hibrida spline dengan polinomial lokal agar dapat memprediksi kasus COVID-19 lebih baik.

\section{DAFTAR PUSTAKA}

Abraham, (2002). "Analysis of hybrid soft and hard computing techniques for forex monitoring systems", in IEEE Proc. International Conference on Fuzzy Systems, vol. 2, 12-17 May 2002, pp. $1616-1622$

Aldila, D., Khoshnawb, S.H.A., Safitri, E., Anwar, Y.R., Bakrya, A.R.Q., Samiadji, B.M., Anugerah, D.A., Alfarizi, M.F.G.H., Ayulani, I.D. dan Salim, S.N. (2020), "A mathematical study on the spread of COVID-19 considering social distancing and rapid assessment: The case of Jakarta, Indonesia", Chaos, Solitons and Fractals, Volume 139, Hal. 1-14, https://doi.org/10.1016/j.chaos.2020.110042.

Aydın, D. (2008), "A comparison of the Nonparametric Regression Models Using Smoothing Spline and Kernel Regression", International Journal of Mathematical, Physical and Engineering Sciences, ISSN 1307-7465, Vol. 2, Number 2, Hal. 75-79, Spring.

Breiman, L., Friedman, J.H., Olshen, R.A., dan Stone, C.J. (1993). Classification and Regression Trees. New York: Chapman and Hall.

Chen, C. dan Huang, H. (2011), "An improved Cp criterion for spline smoothing", Journal of Statistical Planning and Inference, Vol. 141, Hal. 445-452.

Chou, S.M., Lee, T Y., Shao. E, dan Chen, I.F. (2004), "Mining the breast cancer pattern using artificial neural networks and multivariate adaptive regression splines", Expert Systems With Applications, vol. 27, no. 1, pp. 133-142,

Demertzis, K., Tsiotas, D., dan Magafas, L. (2020), Modeling and Forecasting the COVID-19 Temporal Spread in Greece: An Exploratory Approach Based on Complex Network Defined Splines, Int J Environ Res Public Health. Vol.17(13): 4693. doi: 10.3390/ijerph17134693.

Eubank, R.L. (1999), Nonparametric Regression and Spline Smoothing, 2nd ed., Dekker, New York.

Eubank, R. (1988), Spline Smoothing and Nonparametric Regression, New York: Marcel Dekker. Ekum, M. dan Ogunsanya, A. (2020), "Application of Hierarchical Polynomial Regression Models to Predict Transmission of COVID-19 at Global Level", International Journal of Clinical Biostatistics and Biometrics, DOI: 10.23937/2469-5831/1510027.

Friedman, J.H. (1991). "Multivariate Adaptive Regression Splines", The Annals of Statistics, Vol. 19, hal. 1-141.

Haas, H. and Kubin. G. (1998), "A multi-band nonlinear oscillator model for speech", in Conference Record of the Thirty-Second Asilomar Conference on Signals, Systems \& Computers, vol. 1, pp. 338-342.

Hardle, W. K. (1994). Applied Nonparametric Regression. Berlin: Springer-Verlag.

Kim, T.H., Lee., Y.S. and Newbold, P., Spurious. (2004) Nonlinear Regressions in Econometrics, working paper, School of Economics, University of Nottingham, Nottingham NG7 2RD, UK.

Kimeldrof, G. dan Wahba, G. (1971), "Some Result on Tchebycheffian Spline Function", Journal of Mathematical Analysis and Application, Vol. 33, Hal. 82-95.

Kisi, O., and Parmar, K. S. (2016). "Application of least square support vector machine and multivariate adaptive regression spline models in long term prediction of river water pollution". Journal of Hydrology, 534, 104-112.

Lee, T.S dan Chen, I.F. (2005). "A two-stage hybrid credit scoring model using artificial neural networks and multivariate adaptive regression splines", Expert Systems With Applications, vol. 28, no. 4, pp. 743-752. 
Lewis, P. A. W dan Stevens, J. G. (1990). "Nonlinear modeling of time series using Multivariate Adaptive Regression Splines (MARS)". Journal of the American Statistical Association, Vol. 86, 1991 - Issue 416.

Lewis, C. D. (1982). Industrial and Business Forecasting Methods. London: Butterworths.

Liang, H. (2006), "Estimation in partially linear models and numerical comparisons", Computational Statistics and Data Analysis, Vol. 50, Hal. 675-687.

Loader, C. (2004), Smoothing: Local regression techniques, To appear in Handbook of Computational Statistics, Editors: James Gentle, Wolfgang Hardle, Yoichi Mori, SpringerVerlag.

Mukkamala, S. dan Sung. A. H. (2003), "A comparative study of techniques for intrusion detection," in IEEE Proc. 15th International Conference on Tools with Artificial Intelligence, pp. $570-577$.

Susilo A, Rumende CM, Pitoyo CW, Santoso WD, Yulianti M, Herikurniawan H, et al. (2020), "Coronavirus disease 2019: tinjauan literatur terkini", Jurnal Penyakit Dalam Indonesia, Vol. 7(1), Hal. 45-67

Teguh, R., Sahay, A.S. dan Adjib. F.F. (2020), "Pemodelan penyebaran Infeksi COVID-19 di Kalimantan", Jurnal Teknologi Informasi, https://www.researchgate.net/publication/341709835.

Wahba, G. (1990). Spline Model for Observational Data, Society for Industrial and Applied Mathematics, Philadelphia.

Wahba, G. (1983), "Bayesian Confidence Intervals for the cross-validated smoothing spline", Journal of the Royal Statistical Society, series B, Vol. 45, Hal. 133-150

Wang, Y. (1998), "Smoothing spline models with correlated random errors", Journal of the American Statistical Association, Vol. 95, Hal. 341-348. 